\title{
The Influence of Employee Promotion, Upward Downward Communication and Work Environment on Job Satisfaction of PT. Holcim Indonesia, Tbk
}

\author{
Albert Yansen \\ PhD College Student, Human Resource Management Studies Program, \\ University of Negeri Jakarta (Author). \\ E-mail: albertyansen_IM16s3@mahasiswa.unj.ac.id
}

Yetti Supriyati

Human Resource Management Program

University of Negeri Jakarta (Affiliation)

E-mail: y_supriyati@yahoo.com

\begin{abstract}
Kadir
Department of Mathematics Education Program

University of Islam Negeri Syarif Hidayatullah (Affiliation)

E-mail: kadir@uinjkt.ac.id
\end{abstract}

Received: Nov. 12, 2019 Accepted: Dec. 4, 2019 Online published: Jan. 2, 2020

doi:10.5296/ijhrs.v10i1.15797

URL: https://doi.org/10.5296/ijhrs.v10i1.15797

\begin{abstract}
This study aims to determine the influence of employee promotions, upward downward communication, and work environment on employee job satisfaction. This research uses a quantitative approach using a survey method (questionnaire).

Path analysis is used to analyse the data collected. The population in this study were all employees of PT. Holcim Indonesia, Tbk, who have a working period of 10 years and over, totalling 510 people spread across all plants in Indonesia. The number of samples taken in
\end{abstract}


this study were 225 people who were randomly selected.

The results showed that job satisfaction was directly influenced by employee promotions, upward downward communication, and work environment. The study also found that the work environment was influenced by employee promotion and upward downward communication. This study also found that job satisfaction is indirectly influenced by the promotion and upward downward communication through the work environment. Based on these findings it can be concluded that any changes that occur in employee job satisfaction are influenced by employee promotion, upward downward communication, and work environment. Therefore employee job satisfaction, employee promotions, upward downward communication, and work environment can be taken into consideration in making strategic planning for human resource development.

Keywords: promotion, upward downward, environment, satisfaction, smart, indirect

\section{Introduction}

Job satisfaction has always been a key point of discussion among researchers, lecturer and scholars since long. After the foundation of industrialization this serious issue gained enthusiastic attention of researchers, and now it is being applied to each and every organization all around the world. From many decades, this topic is important area of research for us and many researchers investigate the association among job satisfaction and its affecting aspects. Job satisfaction is the level of someone's feeling of pleasure by making a positive assessment of their work and the environment in which they work. This means that job satisfaction as a complex emotional reaction (Wijaya, 2017). This emotional reaction is a result of encouragement, desires, demands and expectations of employees to the work that is associated with the reality felt by employees, causing feelings of pleasure, feeling satisfied, or feeling dissatisfied.

Other researcher, Robbins \& Judge in Hairudin, A (2017) said that there are four ways employees express dissatisfaction, namely: (one). exit; (two). aspiration (voice); (three). loyalty; (four). neglect. Job satisfaction can be improved to obtain maximum performance. Job satisfaction is influenced by a lot of variables.

Promotion is defined as giving a higher position to employees, where higher status means more responsibility. Promotion means employee progress in terms of salary and status as well as improvements in working conditions (R, G., \& Shibu, N., 2014). Promotions are used to fill positions that are more important to fill than current employee positions. This can be filled by external recruitment but employees who have the feasibility and experience must be appointed for their motivation.

Larkin and Larkin in Semegine, E. T., (2010) recommend that downward communication is most effective if top managers communicate directly with direct personnel and personnel directly communicate with their staff. Barker \& Gaut in Owusu Kwateng, K., Vivian Osei, H., \& EkowAbban, E. (2014) said that upward communication can be interpreted as information sent from subordinates to superiors or leaders. This mode of communication serves a variety of needs: often used by employees to communicate valuable information to management. 


\section{Macrothink

Work environment can be described as the environment in which people work. However, all aspects of the work environment are the same or very appropriate when it is considered job satisfaction and also affects employee welfare. (Jain, R., \& Kaur, S., 2014).

This research was to investigate for employee of PT. Holcim Indonesia, Tbk in all plant of Indonesia (Narogong, Cilacap, Tuban and LhokNga). Present PT.Holcim Indonesia, Tbk sold to PT.Solusi Bangun Indonesia, Tbk (Semen Indonesia group). Formerly, PT.Holcim Indonesia, Tbk have sold its assets in Indonesia (divested) due to a decrease in total company performance. Since 2015 the company has laid off more than 400 permanent employees and has changed its internal organizational structure several times including the board of directors and even selected employee candidates from outside the company to get employee job satisfaction for the company's progress. Decrease in job satisfaction of employees of PT. Holcim Indonesia, Tbk seen with the last 3 years the company suffered financial losses, decreased bonuses received by employees each year and the elimination of the employee promotion system namely OPI (Organization Performance Improvement) (www.holcim.co.id).

\section{Methodology}

\subsection{Sampling}

Sampling method was used to determining the questionnaire in this research. The sampling size is determined by using the following Slovin's (1960) formula (Priyono, \& Marnis, 2008): $\mathrm{n}=\mathrm{N} /\left(1+\mathrm{N} \mathrm{e}^{2}\right)$

Where:

$\mathrm{N}$ : Population $=510$ permanent employees (for more than ten years experiences)

e: The Error of Sampling $=5 \%$

n: Sample Size $=225$ respondents (random)

Therefore, based on the calculation above, the sampling size that will be used in this research is 225 respondents.

\subsection{Statistical Test}

Before the path analysis is carried out (SEM PLS), all variables are first tested with a statistical analysis are feasibility test in the questionnaire, validity test, and reliability test. To collect information needed in the study carried out using a questionnaire.

\subsection{Questionnaire Design}

Questionnaire consists of several questions. The questionnaire uses Likert scale in order to determine the point of each question (Joshi, A., Kale, S., Chandel, S., \& Pal, D., 2015). The scale that was used was from 1 to 5, which indicated: 1 . Strongly Often; 2. Often; 3. Rarely; 4. Strongly Rarely; 5 . Never. Likert scale using a scale of 1 to 5 is to eliminate the ambiguity of neutral answer. This scale makes the answer clear.

\subsection{Place and Time of Research}

Research was conducted on permanent employees of PT. Holcim Indonesia, Tbk, which are 


\section{Ml Macrothink}

International Journal of Human Resource Studies

ISSN 2162-3058

2020, Vol. 10, No. 1

located in all plant and surrounding areas (Narogong plant, Cilacap plant, Tuban plant, Lhok Nga - Aceh, and Aggregate Construction Material Directorate). The study was conducted for 6 (six) months, starting from December 20189 until June 2019.

\subsection{Methods}

Research uses survey methods, namely quantitative research that aims to determine status quo variable, and the relationship between the variables studied (Priyono, \& Marnis, 2008). The choice of this method is based on the consideration that research involves four variables whose data comes from a group of respondents who are the same and answer every question that is asked simultaneously. The research approach with this quantitative method is used to analyze the influence of several independent variables used on the dependent variable.

To describe how well the statistical model fits a set of observations (between observed values and the values expected in the model), the global model fit needs to be calculated.

Figure 1 describes the global model fit indices for SEM-based PLS-SEM considering CFA (Hair Jr., J. F., Matthews, L. M., Matthews, R. L., \& Sarstedt, M (2017) and Kadir (2015)).

\begin{tabular}{|c|c|c|}
\hline Fit Indices & Statistical Notation & Formula \\
\hline Construct Reliability & CR & $C R=\frac{\sum\left(\lambda_{n, m}\right)^{2}}{\sum\left(\lambda_{n, m}\right)^{2}+\sum\left(\operatorname{Var}\left(\varepsilon_{n, m}\right)\right)}$ \\
\hline Average Variance Extracted & AVE & Ave $=\frac{\sum(\text { Communalities })^{2}}{n}$ \\
\hline Blindfolding Criteria Index & $\mathrm{F} 2(\mathrm{~A} / \mathrm{B})$ & $F^{2}\left(\frac{A}{B}\right)=\frac{R_{\text {included }}^{2}-R_{\text {encludal }}^{2}}{1-R_{\text {indulded }}^{2}}$ \\
\hline Goodness of Fit & GOF & GOF $=\sqrt{\overline{\text { Communality }} * \overline{R^{2}}}$ \\
\hline Coefficient of Determination & R2 & $R^{2}=1-\left(\frac{L(0)}{L(\alpha)}\right)^{2 / n}$ \\
\hline
\end{tabular}

Figure 1. Indices of global model fit

CFA is a form of factor analysis where it is used to test to which extent a construct or a factor is consistent with the proposed understanding of the nature of the mentioned construct or factor. Before applying a CFA, a

hypothesis has to be developed which is about the underlying measures of proposed hypothesis; by implying these constraints, the proposition has forced the model to be consistent with the theory.

\subsection{Hypothesis}

Hypothesis Formulation:

H1: Employee promotion has positive influences on job satisfaction

$\mathrm{H} 2$ : Upward downward communication has positive influences on job satisfaction

H3: The work environment has positive influences on job satisfaction

H4: Employee promotion has positive influences on work environment

H5: Upward downward communication has positive influences on work environment

H6: Employee promotion has positive influences on job satisfaction

H7: Upward downward communication has positive influences on job satisfaction with work 
environment as intervening variable.

\subsection{Analysis Criteria}

The processing of sample data in this study was carried out by statistical tests using structural equation modeling (SEM). SEM analysis using Partial Least Square (PLS) 2.0 M.3 is done through two stages, namely evaluation of the measurement model (outer model) and evaluation of the structural model (inner model).

The measurement model with reflective indicators is evaluated by convergent validity with the terms average variance extracted (AVE) $>0.5$ of the indicators with loading significant $p$ $<0.05$ and the value of composite reliability (CR) with the value of Cronbach alpha $>0.7$. The stability of these estimates is evaluated using the t-statistic test (if t-statistic $>\mathrm{t}$-value (1.65) at a significant level of 10\%, or t-statistic > t-value (1.96) at the significant level of 5\%) which is obtained through the bootstrapping procedure (Hair Jr., J. F., Matthews, L. M., Matthews, R. L., \& Sarstedt, M., 2017). While the evaluation of inner model is evaluated by looking at the percentage of variance explained by the value $\mathrm{R}$ square for the latent dependent construct using the Stone-Geisser of Q square test where R square is 0.67 (strong), 0.33 (average), 0.19 (weak) and also see the magnitude of the structural path coefficient. Given the sample size in this study is 225 respondents; the researcher uses a PLS-SEM method. PLS is intended for causal-predictive analysis in high complexity situations.

\section{Results}

\subsection{Validity Test}

After testing the instrument for all variables, the outer loading results were obtained as follows:

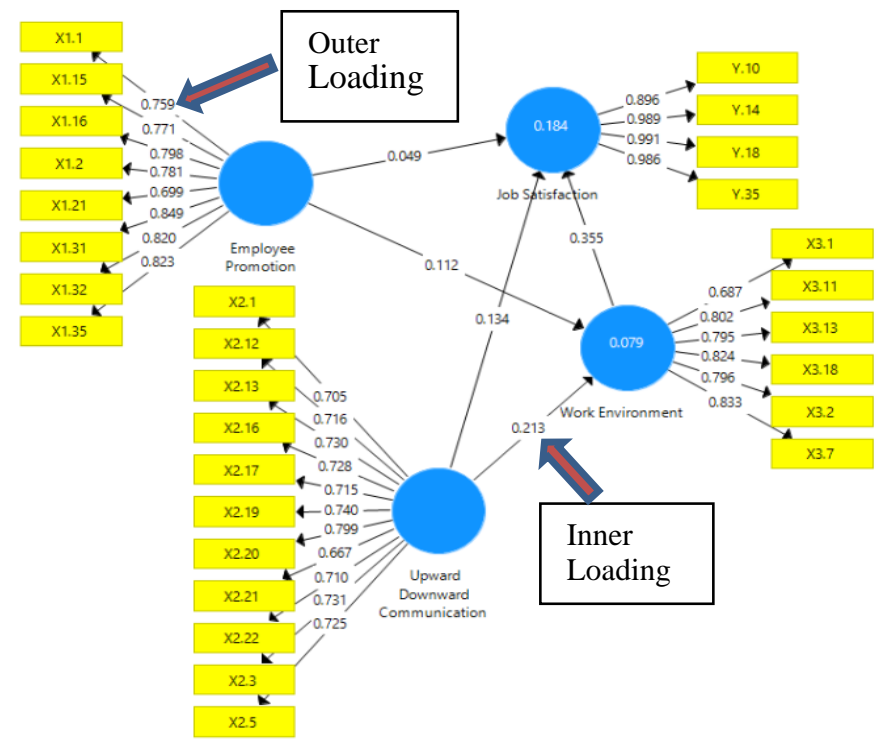

Figure 2. Outer \& Inner Loading models

The outer model test result shows that all items have outer loading more than 0.50 so that the whole points can be used. 


\subsection{Reliability Test}

Table 1. Average Variance Extracted (AVE)

\begin{tabular}{|l|r|r|}
\hline Variable & Original Sample (O) & P Values \\
\hline Employee Promotion & 0.622 & $\mathbf{0 . 0 0 0}$ \\
\hline Job Satisfaction & 0.934 & $\mathbf{0 . 0 0 0}$ \\
\hline Upward Downward Communication & 0.525 & $\mathbf{0 . 0 0 0}$ \\
\hline Work Environment & 0.626 & $\mathbf{0 . 0 0 0}$ \\
\hline
\end{tabular}

Table 2. Composite Reliability (CR)

\begin{tabular}{|l|r|r|}
\hline Variable & Original Sample (O) & P Values \\
\hline Employee Promotion & 0.929 & $\mathbf{0 . 0 0 0}$ \\
\hline Job Satisfaction & 0.983 & $\mathbf{0 . 0 0 0}$ \\
\hline Upward Downward Communication & 0.924 & $\mathbf{0 . 0 0 0}$ \\
\hline Work Environment & 0.909 & $\mathbf{0 . 0 0 0}$ \\
\hline
\end{tabular}

Table 3. Cronbach's Alpha (CA)

\begin{tabular}{|l|r|r|}
\hline Variable & Original Sample $(\mathbf{O})$ & P Values \\
\hline Employee Promotion & 0.917 & $\mathbf{0 . 0 0 0}$ \\
\hline Job Satisfaction & 0.976 & $\mathbf{0 . 0 0 0}$ \\
\hline Upward Downward Communication & 0.910 & $\mathbf{0 . 0 0 0}$ \\
\hline Work Environment & 0.879 & $\mathbf{0 . 0 0 0}$ \\
\hline
\end{tabular}

Table 4 . $\mathrm{R}$ adjust value

\begin{tabular}{|l|r|}
\hline Variable & Original Sample (O) \\
\hline Job Satisfaction & 0.173 \\
\hline Work Environment & 0.071 \\
\hline
\end{tabular}

From Table 1 shown all outer loading bootstrapping factor $>0.5$, AVE value $>0.5$, with significant $<0.05$. Means: the construct

output data is evaluated by convergent validity. Table 2 and Table 3 shown CR value $>0.7$, Cronbach's Alpha $>0.7$, Means: the construct output data is evaluated by composite reliability.

\subsection{Path Coefficient}

Table 5. Direct Path Coefficient

\begin{tabular}{|l|r|r|}
\hline Variable & $\begin{array}{l}\text { Original } \\
\text { Sample } \\
(\mathbf{O})\end{array}$ & $\begin{array}{l}\text { P } \\
\text { Values }\end{array}$ \\
\hline $\begin{array}{l}\text { Employee } \\
\text { Promotion -> } \\
\text { Job Satisfaction }\end{array}$ & 0.049 & $\mathbf{0 . 5 4 6}$ \\
\hline Employee & 0.112 & $\mathbf{0 . 1 7 9}$ \\
\hline
\end{tabular}




\begin{tabular}{|l|l|l|}
\hline $\begin{array}{l}\text { Promotion -> } \\
\text { Work } \\
\text { Environment }\end{array}$ & & \\
\hline $\begin{array}{l}\text { Upward Job } \\
\text { Downward } \\
\text { Communication } \\
\text {-> }\end{array}$ & 0.967 & $\mathbf{0 . 0 4 3}$ \\
Satisfaction & & \\
\hline $\begin{array}{l}\text { Upward Wownward } \\
\text { Down } \\
\text { Communication } \\
\text {-> } \\
\text { Environment }\end{array}$ & 0.213 & $\mathbf{0 . 0 1 1}$ \\
\hline $\begin{array}{l}\text { Work } \\
\text { Environment -> } \\
\text { Job Satisfaction }\end{array}$ & 0.355 & $\mathbf{0 . 0 0 0}$ \\
\hline
\end{tabular}

Table 6. Indirect Path Coefficient

\begin{tabular}{|l|r|r|}
\hline Variable & Original Sample (O) & P Values \\
\hline Employee Promotion -> Job Satisfaction & 0.040 & $\mathbf{0 . 2 2 1}$ \\
\hline Employee Promotion -> Work Environment & & \\
\hline Upward Downward Communication -> Job Satisfaction & 0.076 & $\mathbf{0 . 0 2 8}$ \\
\hline Upward Downward Communication -> Work Environment & & \\
\hline Work Environment -> Job Satisfaction & & \\
\hline
\end{tabular}

The first evaluation on the inner model is seen from the R-Square value or coefficient of determination. Based on table 4, the R-Square value for work satisfaction is 0.173 . This means that job satisfaction can be influenced by employee promotion, upward downward communication, and work environment by $17.3 \%$. While the remaining $82.7 \%$ are influenced by other factors outside of the influence of employee promotion, upward downward communication, and work environment. And R-Square value for work environment is 0.071 . This means that work environment can be influenced by employee promotion, and upward downward communication by $7.1 \%$. While the remaining $92.9 \%$ are influenced by other factors outside of the influence of employee promotion, and upward downward communication.

\subsection{Hypotheses Testing Result}

Base on Table 6 and Table 7, there are seven hypotheses which were tested, as follows:

H1: Employee promotion has positive influence on job satisfaction

$\mathrm{H} 2$ : Upward downward communication has positive influence on job satisfaction

H3: The work environment has positive influence on job satisfaction

H4: Employee promotion has positive influence on work environment

H5: Upward downward communication has positive influence on work environment 
H6: Employee promotion has positive influence on job satisfaction H7: Upward downward communication has positive influence on job satisfaction

H7: Upward downward communication is influence direct positive on the job satisfaction with work environment as intervening variable

\section{Discussion}

Job satisfaction is based on individual attitudes in general towards their work. Someone with a high level of job satisfaction has a positive attitude towards their work and vice versa (Anitha, Z., Dalimunthe, R. F., \& Inneke, Q., 2006). The findings of this research indicate that all facets of job satisfaction are positively related to employee promotion, upward downward communication and work environment. Considering the supported hypotheses, upward downward communication generated the highest path coefficient on job satisfaction. Employee promotion, upward downward communication and work facets significantly predict job satisfaction with a substantial $R$ squared value of range 34 per cent to 84 per cent for direct influence and also R squared value of range 3 per cent to 27 per cent for indirect influence. Therefore, the hypothesis was supported. Promotion opportunities are also an important aspect of a worker's career, urgent, and life. It can have a significant influenced on other job characteristics such as responsibilities, etc. As stated above, the direct relation between upward downward communication and employee job satisfaction has been proved by many studies since the 1950s. The second group of research examining the relations between the internal communication (upward downward communication) and employee job satisfaction shows the dependence between communication and job satisfaction influenced by other variables.

This study is in line with previous researches that found positive relationship and influence employee promotion, upward downward communication and work environment on job satisfaction (Noor Zahid, Khan Aman Ullah, N. I. (2015), Nugraha, M. B. I., \& Surya, I. B. K., (2016), Selvi, E. (2018)).

\section{Recommendation}

This finding is useful especially in determining job satisfaction among employees. High daily expenditure requires employees to find other alternatives in making more influence of job promotion, upward downward communication, and work environment on job satisfaction. The more severe impact to the company is that the employees will look for other work opportunities outside. Therefore, all organizations especially private company sectors should consider promotion opportunities, communication, and work environment for increasing job satisfaction. Since this element is the main focus of all employees, organizations may use the variable as mechanism to enhance satisfaction, communication, work environment and to retain their best talents. A company needs to improve good communication style to improve the employee satisfaction. A company must have. All enforcement elements above by a leader are necessary so that employees are able to maintain their dignity and employee satisfaction.

Future suggestions and developments of the current study may be as follows. First, the input data of the questionnaire survey must be for all employee focus (start with null experiences). 


\section{Macrothink}

International Journal of Human Resource Studies ISSN 2162-3058 2020, Vol. 10, No. 1

Second, may another aspect of satisfaction such as leadership, etc. also which must suggest in research.

This study offers important policy insight for all position in company who seek to increase job satisfaction among their job.

\section{References}

Anitha, Z., Dalimunthe, R. F., \& Inneke, Q. (2006). Hibah kompetisi.

Gopinath, R., \& Shibu, N. (2014). A Studi On Promotion and Transfer in BSNL With Reference To Job Satisfaction in Madurai SSA.

Hair Jr., J. F., Matthews, L. M., Matthews, R. L., \& Sarstedt, M. (2017). PLS-SEM or CB-SEM: updated guidelines on which method to use. International Journal of Multivariate Data Analysis. https://doi.org/10.1504/IJMDA.2017.087624

Hairudin, A. (2017). Pengaruh kompensasi dan komunikasi terhadap kepuasan kerja dan kinerja karyawan pabrik pada pt. agro sarimas indonesia kabupaten indragiri hilir, IX(1), 620-633.

Jain, R., \& Kaur, S. (2014). Impact of Work Environment On Job. International Journal of Scientific and Research Publications, 4(1), 1-8.

Joshi, A., Kale, S., Chandel, S., \& Pal, D. (2015). Likert Scale: Explored and Explained. British Journal of Applied Science \& Technology. https://doi.org/10.9734/bjast/2015/14975

Kadir. (2015). Analisis Faktor. PT.Raja Grafindo Persada.

Noor, Z., Khanl, A. U., \& Naseem, I. (2015). Impact of job promotion and job advancement on job satisfaction in universities of KPK Province of Pakistan. Science International Journal (Lahore), 27(2), 1499-1505.

Nugraha, M. B. I., \& Surya, I. B. K. (2016). Pengaruh Kompensasi, Lingkungan Kerja Dan Promosi Jabatan Terhadap Kepuasan Kerja, 5(1), 59-87.

Owusu, K. K., Vivian, O. H., \& EkowAbban, E. (2014). Organizational Communication in Public Health Institutions. International Journal of Business and Management, 9(11), 179-188. https://doi.org/10.5539/ijbm.v9n11p179

Priyono, \& Marnis. (2008). Manajemen Sumber Daya Manusia. Manajemen Sumber Daya Manusia.

Putra, A. N., \& Welly, J. (2015). Analysing Engagement of Outsourve Employee Study Case : PT Bravo Humanika Persada. Journal of Business and Management.

Selvi, E. (2018). Pengaruh Pemberian Kompensasi Terhadap Kepuasan Kerja Karyawan Dan Lingkungan Kerja Sebagai Variabel Intervening Di Dinas Pendidikan Kabupaten Karawang. Retrieved from https://penelitian.stie11april-sumedang.ac.id/?s=evi+selvi 


\section{Macrothink}

International Journal of Human Resource Studies

ISSN 2162-3058 2020, Vol. 10, No. 1

Tariszka-Semegine, E. (2012). Organizational internal communication as a means of improving efficiency. European Scientific Journal, 8(15).

Wijaya, C. (2017). Perilaku Organisasi. Ebook www.holcim.co.id

\section{Copyright Disclaimer}

Copyright for this article is retained by the author(s), with first publication rights granted to the journal.

This is an open-access article distributed under the terms and conditions of the Creative Commons Attribution license (http://creativecommons.org/licenses/by/4.0/). 